\title{
PERBANDINGAN FUNGSI KOGNITIF SEBELUM DAN SESUDAH DIALISIS PADA SUBJEK PENYAKIT GINJAL KRONIK YANG MENJALANI HEMODIALISIS
}

\author{
${ }^{1}$ Siska A. Manus \\ ${ }^{2}$ Emma Sy. Moeis \\ ${ }^{3}$ Veny Mandang \\ ${ }^{1}$ Kandidat Skripsi Fakultas Kedokteran Universitas Sam Ratulangi Manado \\ ${ }^{2}$ Bagian Ilmu Penyakit Dalam Universitas Sam Ratulangi Manado \\ Email: chikamanus@gmail.com
}

\begin{abstract}
Chronic Kidney Disease (CKD) is a pathophysicological process with various causes, resulting in the decline of progressive kidney function and in kidney failure. Currently, CKD cases are rising quickly particularly in developing countries and have become the main health problem worldwide because it has been the risk factor of cardiovascular diseases. CKD can cause failure of organs due to the increased toxin level. The increase of blood ureum level could harm all cells, including neuron cells. One of the therapies of CKD is hemodyalisis. This study aimed to obtain the ratio of cognitive function before and after undergoing hemodyalisis among CKD patients. This was a descriptive study using the primary data obtained directly from the patients undergoing hemodyalisis at the hemodyalisis unit, Department of Internal Diseases Prof. Dr. R. D. Kandou Hospital, Manado. The population in this study was patients who had undergone hemodyalisis more than 208 times or for 2 years and had met the inclusion criteria. The results showed that CDK male patients were $43,3 \%$ and female patients $56,7 \%$. Before undergoing hemodialysis, the average ureum level was 124.7, and after undergoing hemodyalisis, the average ureum level was 97.3 with 20.4\% Urea Reduction Rate (URR). Before undergoing hemodialysis, the average cognitive function was 27.6, and after hemodialysis, the average rate was 28,6. Conclusion: There was a significant decrease of average blood ureum level and a significant increase of cognitive function among CKD patients who had undergone hemodyalisis.
\end{abstract}

Keywords: chronic kidney disease, hemodyalisis, ureum, cognitive function

\begin{abstract}
Abstrak: Penyakit Ginjal Kronik (PGK) adalah suatu proses patofisiologi dengan penyebab yang beragam, mengakibatkan penuruan fungsi ginjal yang progresif, dan biasanya berakhir dengan gagal ginjal. Kasus Penyakit Ginjal Kronik saat ini meningkat dengan cepat terutama di negaranegara berkembang dan telah menjadi masalah utama kesehatan di seluruh dunia karena merupakan faktor resiko terjadinya penyakit jantung dan pembuluh darah. PGK dapat mengakibatkan peningkatan kadar ureum dalam tubuh yang dapat merusak semua sel termasuk sel neuron. Penelitian ini bertujuan untuk mengetahui perbandingan fungsi kognitif sebelum dan sesudah dialisis pada pasien PGK. Penelitian ini mengguakan metode deskriptif berdasarkan data primer yang didapatkan secara langsung dari pasien yang menjalani terapi hemodialisis di Unit Hemodialisis Bagian Ilmu Penyakit Dalam RSUP Prof. Dr. R. D. Kandou Manado. Populasi penelitian yaitu pasien PGK yang telah menjalani terapi hemodialisis. Hasil penelitian menunjukkan bahwa pasien PGK berjenis kelamin laki-laki sebesar 43,3\% dan perempuan sebesar $56,7 \%$. Sebelum menjalani hemodialisis nilai rerata ureum 124,7 dan sesudah nilai rerata ureum menjadi 97,3 dengan rerata Urea Reduction Rate (URR) 20,4\%. Sebelum menjalani hemodialisis rerata fungsi kognitif 27,6 dan sesudah hemodialisis rerata menjadi 28,6. Simpulan: Terjadi penurunan bermakna dari nilai rerata ureum serta terjadi peningkatan bermakna dari nilai rerata fungsi kognitif sesudah pasien PGK menjalani hemodialisis.
\end{abstract}

Kata kunci: penyakit ginjal kronik, hemodialisis, ureum, fungsi kognitif 
Penyakit Ginjal Kronik (PGK) adalah suatu proses patofisiologi dengan penyebab yang beragam, mengakibatkan penuruan fungsi ginjal yang progresif dan biasanya berakhir dengan gagal ginjal. ${ }^{1}$ Kasus penyakit ginjal kronik saat ini meningkat dengan cepat terutama di negara-negara berkembang. Penyakit Ginjal Kronik telah menjadi masalah kesehatan utama di seluruh dunia, karena selain merupakan faktor resiko terjadinya penyakit jantung dan pembuluh darah, meningkatkan angka kesakitan dan kematian dari penyakit bukan infeksi, Penyakir Ginjal Kronik juga akan menambah beban sosial dan ekonomi baik bagi penderita dan keluarga. ${ }^{2}$ Seiring dengan pertambahan penduduk di Amerika diperkirakan kasus penderita dengan Penyakit Ginjal Kronik naik di atas 570.000 pada tahun 2011. Tingkat kasus Penyakit Ginjal Kronik lazim mencapai 1.738 per juta penduduk, meningkat 2,1\% dari 2008, dan konsisten dengan kenaikan serupa per tahun sejak tahun 2002. ${ }^{3}$ Angka kejadian penderita Penyakit Ginjal Kronik di Indonesia tahun 2002 sebesar 2.149 meningkat menjadi 4.656 pada tahun 2006. Adapun tingkat prevalensi perjuta populasi tahun 2002 adalah 10,2\%, tahun 2.003 sebesar 11,7\%, tahun 2004 sebesar 13,8\%, tahun 2005 sebesar 18,4\%, tahun 2006 sebesar $23,4 \%{ }^{1}$

Penyakit Ginjal Kronik dapat menyebabkan gangguan pada organ tubuh. Hal ini terjadi karena toksin yang seharusnya dikeluarkan oleh ginjal tidak dapat dikeluarkan karena keadaan ginjal yang mengalami gangguan. Salah satu hal yang terjadi karena rusaknya ginjal adalah peningkatan kadar ureum dalam tubuh yang dapat merusak semua sel termasuk sel neuron. ${ }^{1}$ Salah satu tindakan terapi pengganti ginjal adalah dengan hemodialisis. Walaupun masih ada alternatif terapi pengganti ginjal yang lain seperti peritoneal dialisis dan transplantasi ginjal tetapi penderita PGK lebih banyak yang memilih hemodialisis. ${ }^{4}$

Hemodialisis merupakan terapi pengganti ginjal yang dilakukan dengan mengalirkan darah ke dalam tabung ginjal buatan yang bertujuan untuk mengeliminasi sisa-sisa metabolisme protein dan koreksi gangguan keseimbangan elektrolit antara kompartemen dialisat melalui membran semipermeable. $^{5,6}$ Hemodialisis perlu dilakukan untuk mengganti fungsi ekskresi ginjal sehingga tidak terjadi gejala uremia yang lebih berat. ${ }^{7}$

\section{METODE PENELITIAN}

Penelitian ini bersifat deskriptif dimana membuat deskripsi tentang perbedaan ureum dan fungsi kognitif sebelum dan sesudah dilakukan hemodialisis pada pasien Penyakit Ginjal Kronik yang menjalani hemodialisis di Unit Hemodialisis Bagian Ilmu Penyakit Dalam RSUP Prof. Dr. R. D. Kandou Manado. Populasi penelitian ini yaitu pasien yang menjalani terapi hemodialisis. Metode pengambilan sampel menggunakan purposive sampling yaitu pengambilan sampel dilakukan hanya pada pasien Penyakit Ginjal Kronik yang sesuai dengan persyaratan sampel yang diperlukan.

Kriteria inklusi yaitu pasien PGK yang telah menjalani hemodialisis sebanyak lebih dari 208 kali atau telah menjalani terapi hemodialisis selama 2 tahun dengan perhitungan 2 kali terapi dalam seminggu serta pasien dalam keadaan sepenuhnya sadar. Variable penelitian ini yaitu umur, jenis kelamin, fungsi kognitif sebelum dan sesudah hemodialisis yang dinilai dengan tes Mini Mental State Examination (MMSE), serta ureum sebelum dan sesudah hemodialisis. Penelitian ini diawali dengan pengumpulan data kepada setiap pasien yang termasuk dalam kriteria inklusi di Unit Hemodialisis Bagian Ilmu Penyakit Dalam RSUP Prof. Dr. R. D. Kandou Manado selama bulan Desember 2014 Januari 2015 kemudian dikelompokan berdasarkan variabel penelitian.

\section{HASIL PENELITIAN}

Pada penelitian ini ditemukan 30 pasien PGK yang menjalani hemodialisis di Unit Hemodialisis Bagian Ilmu Penyakit Dalam RSUP Prof. Dr. R. D. Kandou Manado yang sesuai dengan kriteria 
inklusi. Proporsi responden dengan jenis kelamin perempuan $(56,7 \%)$ lebih besar dibandingkan dengan laki-laki (43,3\%). Umur maksimal yang didapat 80 tahun dan minimal umur 30 tahun dengan nilai rerata 53 tahun.

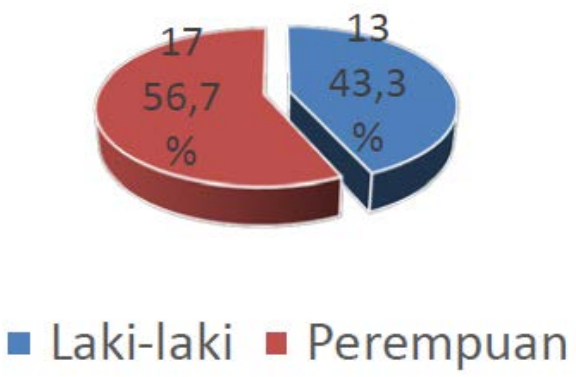

Gambar 1. Distribusi Frekuensi Berdasarkan Jenis Kelamin

Untuk menentukan besarnya tingkat penurunan ureum dalam suatu proses hemodialisis, harus diketahui kadar ureum dalam darah baik pada saat sebelum hemodialisis maupun sesudah hemodialisis. Ini dapat dilakukan dengan melakukan pengujian sampel darah pasien PGK. ${ }^{8}$ Hasil uji statistik menunjukkan rerata kadar ureum sebelum dilakukan hemodialisis 124,7 dan mengalami penurunan sesudah dilakukan hemodialisis menjadi 97,3.

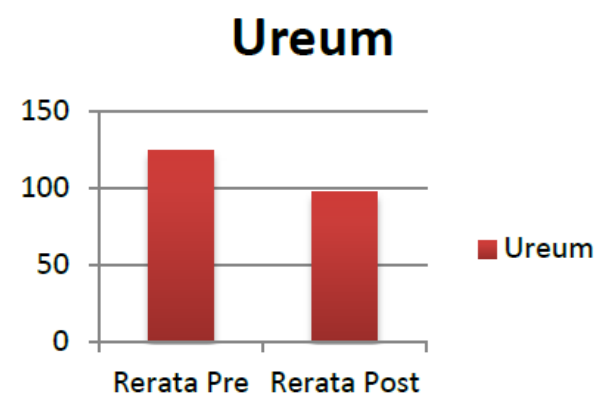

Gambar 2. Rerata ureum sebelum dan sesudah hemodialisis

Salah satu cara untuk menilai fungsi kognitif seseorang ialah tes Mini Mental State Examination (MMSE) yang diperkenalkan oleh Folstein tahun 1971. MMSE digunakan sebagai alat untuk mendeteksi adanya gangguan kognitif pada seseorang/ individu, mengevaluasi perjalanan suatu penyakit yang berhubungan dengan proses penurunan kognitif, dan memonitor respon terhadap pengobatan. ${ }^{8}$ Hasil uji statistik menunjukkan rerata fungsi kognitif sebelum dilakukan hemodialisis 27,6 dan mengalami penurunan sesudah dilakukan hemodialisis menjadi 28,5.

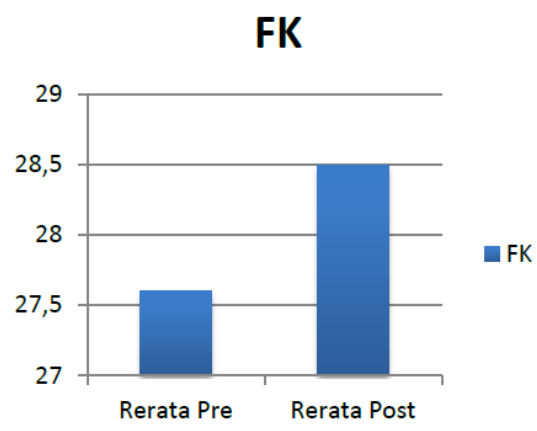

Gambar 3. Rata-rata fungsi kognitif sebelum dan sesudah hemodialisis.

Frekuensi gangguan fungsi kognitif pada pasien PGK sangat tinggi. ${ }^{9}$ Salah satu penyebab yang diduga memperberat gangguan fungsi kognitif tersebut ialah sindrom azotemia yang terjadi karena peningkatan kadar ureum dan kreatinin dalam darah. Melati, ${ }^{10}$ dalam penelitiannya menyatakan terdapat hubungan bemakna antara fungsi kognitif dan ureum kreatinin.

Uremic encephalopathy adalah gangguan otak yang disebabkan oleh gagal ginjal kronis. Kelainan ini merupakan proses yang kompleks dan terdapat kaitan dengan toksin yang terjadi pada gagal ginjal Manisfestasinya meliputi gejala ringan seperti menurunnya fungsi kognitif, kelemahan dan kelelahan sampai gejala yang lebih berat seperti koma. Tingkat keparahan uremic encephalopathy tergantung dari laju penurunan fungsi ginjal. ${ }^{11}$

\section{SIMPULAN}

Berdasarkan hasil penelitian terjadi penurunan bermakna dari nilai rerata kadar ureum darah serta terjadi peningkatan bermakna dari nilai rerata fungsi kognitif sesudah pasien penyakit ginjal kronik menjalani hemodialisis. 
SARAN

Disarankan kepada pasien untuk:

1. Menjaga pola makan dan minum untuk mengatur keseimbangan cairan dan elektrolit

2. Rutin melakukan hemodialisis 2 kali/seminggu dengan durasi 4-5 jam.

\section{DAFTAR PUSTAKA}

1. Suwitra Ketut. Gagal Ginjal Kronik. In: Buku Ajar Penyakit Dalam Jilid II. Ed 5. Jakarta: Departemen Ilmu Penyakit dalam, 2009; p.1035-40.

2. Barsoum RS. Chronic kidney Disease in The Developing World. N Engl J Med. 2006;354(10):997-9.

3. United States Renal Data System. Atlas ESRD International Comparisons. [cited 10 Oktober 2014]. Available from: http://www.usrds.org/2013/pdf/v2_ch1 2_13.pdf

4. Prodjosudjaji W, Suhardjono A. End-stage renal disease in Indonesia: Treatment and Development. Ethn Dis. 2009;19(1):33-6.

5. Rahardjo P, Susalit E, Suhardjono. Hemodialisis. In: Aru W Sudoyo, Bambang S, Alwi I, Simadibrata MK, Setiati S (Editors). Buku Ajar Ilmu
Penyakit Dalam. Jakarta: Pusat Penerbitan Departemen Ilmu Penyakit Dalam FKUI, 2006; p. 590-1.

6. Gatot D. Rasio Reduksi Ureum Dializer 0,90; 2,10 dan 2 Dializer Seri 0,90 dengan 1,20 [Skripsi]. Medan: Fakultas Kedokteran USU; 2003.

7. Black JM, Hawks JH. Medical Surgical Nursing Clinical Management for Positive Outcome (7th ed.). Philadelphia: WB Saunders Company, 2005; p. 576-611.

8. Turana Y, Mayza A, Luwempouw SF. Pemeriksaan Status Mini Mental pada usia lanjut di Jakarta. Medika. 2004;30:563-68.

9. Susianti N. Profil Fungsi Kognitif Pasien Gagal Ginjal Kronik yang Menjalani Hemodialisis. Neurona. 2015;32:1-8.

10. Melati S. Faktor-Faktor yang Berhubungan dengan Fungsi Kognitif pada Pasien Gagal Ginjal Terminal yang Menjalani Hemodialisis. Neurona. 2014;35:1-7.

11. Bucurescu G. Neurological Manifestations of Uremic Encephalopathy. 13 Februari 2014. [cited 2015 Oct 30]. Available from:

http://emedicine.medscape.com/article/ 1135651-overview\#showall. 